This item was submitted to Loughborough's Research Repository by the author.

Items in Figshare are protected by copyright, with all rights reserved, unless otherwise indicated.

\title{
Employees' external representation of their workplace: key antecedents
}

PLEASE CITE THE PUBLISHED VERSION

PUBLISHER

(C) Elsevier

VERSION

AM (Accepted Manuscript)

LICENCE

CC BY-NC-ND 4.0

REPOSITORY RECORD

Lages, Cristiana R.. 2019. "Employees' External Representation of Their Workplace: Key Antecedents". figshare. https://hdl.handle.net/2134/9197. 
This item was submitted to Loughborough's Institutional Repository (https://dspace.lboro.ac.uk/) by the author and is made available under the following Creative Commons Licence conditions.

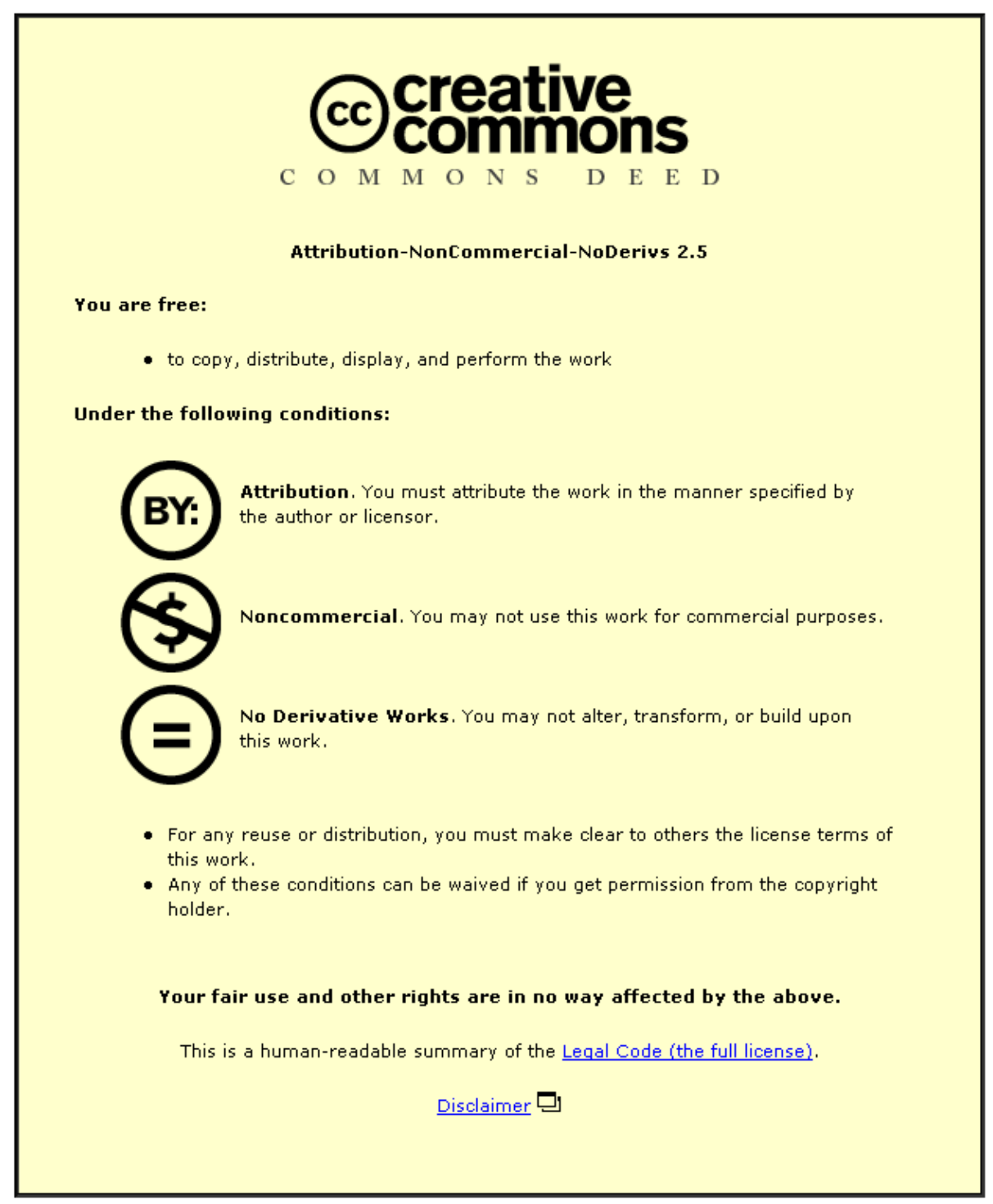

For the full text of this licence, please go to: http://creativecommons.org/licenses/by-nc-nd/2.5/ 


\section{Employees' External Representation of their Workplace: \\ Key Antecedents}

Cristiana Raquel Lages, Loughborough University, U.K.

Submission: October 2009

Revision: July 2010, June 2011

Acceptance: September 2011

Cristiana Raquel Lages acknowledges the Portuguese Science and Technology Foundation -FCT- for financial support (BD111502002) and the company's employees who provided invaluable assistance. The author gratefully acknowledges the valuable comments on earlier versions of this manuscript from Jeroen Schepers, Eindhoven University of Technology; Miguel Pina e Cunha, Universidade Nova de Lisboa; Wilson Ng, University of Westminster; Matthew Robson, University of Leeds; Julien Schmitt, Aston University; and Kevin Daniels, John Cadogan, and Philip Stern, University of Loughborough. Send correspondence to Cristiana Raquel Lages, The School of Business and Economics, Loughborough University, Sir Richard Morris Building, Loughborough, Leicestershire, LE11 3TU, United Kingdom. Phone: 00441509228829 (Email: C.Costalages@lboro.ac.uk). 


\begin{abstract}
Drawing on attitude theory, this study investigates the drivers of employees' expression of favorable opinions about their workplace. Despite its theoretical and managerial importance, the marketing literature largely ignores the topic. This study advances prior research by developing, and empirically testing, a conceptual framework of the relationship between workgroup support and favorable external representation of the workplace, mediated by emotional responses to this support. The present research investigates four new relationships: between workgroup support and emotional exhaustion, workgroup support and organizational commitment, workgroup support and job satisfaction, and emotional exhaustion and external representation of the workplace. Based on a sample of over 700 frontline service employees, this study finds that workgroup support affects favorable external representation of the workplace through various emotional responses (i.e., emotional exhaustion, job satisfaction and organizational commitment). In addition, the results identify employees' organizational commitment as the most important determinant of favorable external representation of the workplace, followed by job satisfaction and reduced emotional exhaustion. These results suggest that companies should develop practices that encourage workgroup support and organizational commitment to achieve favorable external representation of the workplace.
\end{abstract}

Keywords: attitude theory, workgroup support, external representation of the workplace, frontline service employees. 


\section{INTRODUCTION}

Drawing on Bagozzi's (1992) attitude theory, this study develops an external representation model by investigating how workgroup support ultimately drives employees' external representation of the workplace, mediated by employees' emotional responses. External representation reflects employees' verbal expressions about the workplace which shape a company's image to outsiders (Bettencourt and Brown, 2003). External representation is a critical issue in today's competitive environment as external representation drives organizational effectiveness and performance (cf. Podsakoff, Ahearne, and MacKenzie, 1997; George and Bettenhausen, 1990).

Fortune magazine, for example, publishes an annual list of the "100 Best Companies to Work For" based on several criteria that represent employees' opinions about their workplaces. This list influences many candidates searching for jobs at quality companies worldwide. Likewise, companies that rank high on Fortune's list can recruit quality professionals, which ultimately will affect the company's performance. As such, understanding the factors that lead employees to voice a positive opinion of their workplace (favorable external representation) can benefit all firms.

This study uses Bagozzi’s (1992) reformulation of attitude theory (appraisal $\rightarrow$ emotional responses $\rightarrow$ coping responses/behavior) as a general theoretical framework to advance prior research in Marketing. The underlying premise of this theory is that the impact of appraisal on behavior is mediated by emotional responses. Accordingly, this research explores employees' behavior (i.e., favorable external representation) that results from their emotional responses, namely emotional exhaustion, organizational 
commitment, job satisfaction, which in turn are a consequence of employees' appraisal process, that is, workgroup support.

Experienced members of the workgroup who mentor less senior employees provide valuable support by corroborating and improving employees' views of themselves and their abilities (Hartline, Maxham, and McKee, 2000; Van Maanen and Schein, 1979). In particular, a supervisor's support can enable employees to gain new capabilities through direct instruction and the allocation of challenging tasks (Lankau and Scandura, 2002). Additionally, since supervisors are a source of job-related information and know-how (Janssen and VanYperen, 2004), employees can learn with them how to deal effectively with work problems and opportunities. Finally, by providing feedback and active listening, supervisors offer crucial support to assist employees in solving problems (Kram, 1985) and in developing their thinking (Lankau and Scandura, 2002). In essence, a work environment which promotes employees' support from their colleagues, direct supervisors and management leads to more positive emotional responses and ultimately to a favorable external representation of the workplace.

This research contributes to the Marketing literature in four respects. First, anchored in Bagozzi's (1992) reformulation of attitude theory, this study develops a new conceptual framework, which incorporates workgroup support as an appraisal process; emotional exhaustion, job satisfaction and organizational commitment as emotional responses; and favorable external representation as a coping response/behavior.

Second, this research theoretically proposes and empirically tests three unexplored relationships between workgroup support and emotional responses, namely between 
workgroup support and emotional exhaustion, workgroup support and organizational commitment, and workgroup support and job satisfaction.

Third, given that literature (cf. Bettencourt and Brown, 2003; Bettencourt, Brown, and MacKenzie, 2005) largely ignores the role of emotional exhaustion in determining external representation of the workplace, this study fills a gap by including emotional exhaustion as an emotional response and investigating its impact on external representation of the workplace.

Fourth, and in contrast to most empirical studies in the field, this study investigates the indirect and total effects among variables as well as the relative importance of key antecedents.

The next section develops a conceptual framework, which comprises nine hypotheses. Following the development of the hypotheses, this paper discusses the methodology and results of the empirical study. The conclusion presents a discussion of the implications of the results as they advance Marketing theory and inform managers.

\section{CONCEPTUAL FRAMEWORK}

External representation reflects the verbal expression of employees' opinion with regard to the organization's image (Bettencourt and Brown, 2003). Because of its importance in today's competitive environment, this study aims to better understand the drivers of favorable external representation of the workplace. To do so, this study proposes a conceptual framework anchored in Bagozzi’s (1992) reformulation of attitude theory (appraisal process $\rightarrow$ emotional responses $\rightarrow$ coping responses/behavior), in which employee workgroup support is an appraisal process, organizational commitment, 
job satisfaction, and emotional exhaustion are emotional responses, and favorable external workplace representation are coping responses/behavior. Accordingly, anchored in the attitude theory, this paper suggests a mediating role of emotional responses in the relationship between workgroup support and favorable external representation.

\subsection{Attitude theory}

Based on an assessment and critique of three attitude theories - reasoned action, planned behavior, and the theory of trying — Bagozzi (1992) deepens general attitude theory by introducing self-regulatory processes. He argues that these self-regulatory processes represented in a sequence of appraisal processes, emotional reactions and coping responses, guide behavior. Specifically, in the appraisal process, individuals assess situational conditions attributed to another party (Lazarus, 1991). This appraisal process leads to emotions, which ultimately induce coping responses (behavior). For instance, when an individual experiences a pleasant event, he or she then feels a sense of satisfaction and pleasure, which subsequently guides the individual's behavior to maintain, increase or share the outcome with others (Bagozzi, 1992). In contrast, Bagozzi argues, when an individual experiences an unpleasant event he or she may feel dissatisfied and distressed, which in turn results in behaviors aimed at reducing or eliminating the outcome.

Based on Bagozzi’s (1992) work, Figure 1 presents the proposed conceptual framework of the antecedents of external representation. The conceptual framework hypothesizes that appraisal (workgroup support) leads to emotional responses (i.e., emotional exhaustion, job satisfaction and organizational commitment), which in turn drive coping responses (behavior) (i.e., an employee representing his/her company in a 
favorable light). Hence, the model suggests that emotions have a mediating role in the relationship between appraisal and behavior. In particular, emotional exhaustion, job satisfaction and organizational commitment mediate the impact of workgroup support on external representation of the workplace.

Figure 1 here.

\subsection{Research Hypotheses}

Research in Marketing does not explore the relationship between workgroup support and emotional exhaustion. To date, most studies focus on the relationship between organizational support and burnout/emotional exhaustion. Emotional exhaustion represents a lack of energy and a sense of being drained as a result of extreme psychological demands (Hewlin, 2009; Babakus, Cravens, Johnston, and Moncrief, 1999; Singh, Goolsby, and Rhoads, 1994). Despite being distinct concepts (Self, Holt, and Schaninger, 2005), organizational support theory may be the basis to understand workgroup support. Organizational support reduces strains in the workplace by satisfying employees' needs for emotional support (Rhoades and Eisenberger, 2002). When employees feel that they receive social support from others, they tend to experience less stress, less anxiety (Cropanzano, Howes, Grandey, and Toth, 1997) and less emotional exhaustion. Emotional exhaustion is particularly likely to develop in demanding, peopleoriented jobs that require constant personal interactions that can stimulate emotional reactions (Singh et al., 1994). Because frontline service employees (FSEs) often work in 
conditions that lead to emotional exhaustion, organizations need to understand and help employees who face stressful situations at work (Armeli, Eisenberger, Fasolo, and Lynch, 1998). Supportive service organizations tend to create and nurture worker cooperation so that employees can provide support to their co-workers when needed (Cropanzano et al., 1997). Given that workgroup support is the degree to which FSEs socialize in a positive and supportive way with other employees (Hartline et al., 2000) and given that organizational support can reduce emotional exhaustion (Lee and Ashforth, 1996), this study proposes a new hypothesis. $\mathrm{H}_{1}$ : Workgroup support negatively affects employees' emotional exhaustion.

Organizational commitment has been a top management research priority for several decades (e.g., Aryee and Chayt, 1994; Allen and Meyer, 1993; Boshoff and Mels, 2000; Jaramillo, Mulki, and Marshall, 2005; Johnson, Groff, and Taing, 2009; Strauss, Griffin, and Rafferty, 2009). Organizational commitment represents the strength of an individual's identification with and contribution to a particular organization (Mathieu and Zajac, 1990; Mowday, Steers, and Porter, 1979; Porter, Steers, Mowday, and Boulian, 1974). Most definitions of organizational commitment vary but all assert that organizational commitment involves a bond between the individual and his or her organization (Mathieu and Zajac, 1990). Conceptually, organizational commitment has three dimensions: 1) an employee's belief in and acceptance of the organization's goals and values 2) a willingness to exert high levels of effort for the organization, and 3) a strong desire to continue working for the organization (Mowday, Porter, and Steers, 1982; Mowday et al., 1979). This perspective aligns with the view of organizational 
commitment as a dynamic, positive attitude toward the organization (Johnston, Parasuraman, Futrell, and Black, 1990).

Workgroup support enhances organizational commitment for several reasons. Workgroup socialization encourages relationships between new employees and their mentors (Van Maanen and Schein, 1979) and contributes to employee cohesiveness, which leads to a stronger identification with the organization (Mathieu and Zajac, 1990). Additionally, workgroup support can help employees feel more comfortable in their roles, which in turn tends to enhance their affective commitment to the organization (cf. Allen and Meyer, 1990). Finally, employees who feel support tend to offer affiliation and loyalty in return (Eisenberger, Fasolo, and Davis-LaMastro, 1990; Settoon, Bennett, and Liden, 1996). Gouldner's (1960) norm of reciprocity, in which employees react favorably to other employees' positive and supportive socialization, underlies a new relationship, thus leading to the second hypothesis. $\mathrm{H}_{2}$ : Workgroup support positively affects employees' organizational commitment.

Job satisfaction, a key and current topic in Management (e.g., Riggle, Edmondson, and Hansen, 2009; Kim, Knight, and Crutsinger, 2009; Snipes, Oswald, LaTour, and Armenakis, 2005) and Marketing (e.g., Alexandrov, Babakus, and Yavas, 2007), reflects an individual's psychological well-being on the job (Singh et al., 1994). Research in Marketing primarily focuses on the relationship between organizational support and job satisfaction. Employees who perceive high organizational support tend to rate their satisfaction higher than those who do not, because they consider their job more pleasant and feel happy at work (Rhoades and Eisenberger, 2002). Organizational support also helps satisfy employees' socio-emotional needs in the workplace, namely the need for 
esteem, social approval, affiliation, respect, care and emotional support (Armeli et al., 1998; Eisenberger, Huntington, Hutchison, and Sowa, 1986). In addition, organizational support suggests the availability of help when necessary (Rhoades and Eisenberger, 2002). Thus, by satisfying socio-emotional needs and providing aid when necessary, organizational support contributes to job satisfaction (Rhoades and Eisenberger, 2002). Empirical evidence of a strong, positive effect of perceived organizational support on job satisfaction (e.g., Riggle et al., 2009) leads to the third hypothesis. $\mathrm{H}_{3}$ : Workgroup support positively affects employees' job satisfaction.

Recent research encourages analysis of the effects of burnout and emotional exhaustion on job-related attitudes and behavior (Babakus et al., 1999). The relationship between emotional exhaustion and organizational commitment is negative in the case of nurses (Leiter and Maslach, 1988), healthcare workers (Mulki, Jaramillo, and Locander, 2006), salespeople (Babakus et al., 1999), and public service lawyers (Jackson, Turner and Brief, 1987). Leiter and Maslach (1988) suggest that a high level of burnout leads to diminished organizational commitment because employees who feel emotionally exhausted due to their work tend not to accept or wish to achieve organizational goals. Emotionally exhausted employees respond to others in an uncaring and disinterested way, do not feel fulfilled with their jobs, and consequently tend to feel less committed to the organization (Singh et al., 1994). More formally, $\mathrm{H}_{4}$ : Emotional exhaustion negatively affects organizational commitment.

Emotional exhaustion usually relates to diminished job satisfaction (Lee and Ashforth, 1996). Singh et al. (1994) argue that burnout results from an assessment procedure whereby employees appraise job demands in relation to their resources, the 
outcome of which influences employee job satisfaction. In addition, they argue that burnout relates to job satisfaction because both reflect emotional responses to the job. Recent research confirms the negative impact of emotional exhaustion on job satisfaction (Babakus et al., 1999; Karatepe, 2006). More formally, consider the following hypothesis. $\mathrm{H}_{5}$ : Emotional exhaustion negatively affects job satisfaction.

This study presents job satisfaction as an antecedent of organizational commitment (Babakus, Yavas, Karatepe, and Avci, 2003; Brashear, Boles, Bellenger, and Brooks, 2003; Singh, Verbeke, and Rhoads, 1996). Brown and Peterson's (1993) work underlines a predominant effect of job satisfaction on organizational commitment. A possible explanation for the direction of this causality is that job satisfaction is "more specific, less stable, and more rapidly formed" than organizational commitment (MacKenzie, Podsakoff, and Ahearne, 1998: 90). The positive effect of job satisfaction on organizational commitment is empirically confirmed in different settings: in the context of salespeople (Johnston et al., 1990), customer service representatives (Singh et al., 1996), business-to-business salespeople (Brashear et al., 2003), and frontline bank employees (Babakus et al., 2003). More formally, $\mathrm{H}_{6}$ : Job satisfaction positively affects organizational commitment.

To date, no known study addresses the relationship between emotional exhaustion and favorable external representation of the workplace. Nevertheless, recent research finds that emotional exhaustion negatively predicts employee behaviors that go beyond the key job requirements and are beneficial to the organization (Cropanzano, Rupp, and Byrne, 2003; O’Reilly and Chatman, 1986). As a consequence of disrupted workplace relationships, employees become less willing to use their time to help the organization in 
tasks not mentioned in their contract (cf. Cropanzano, Rupp, Mohler, and Schminke, 2001). Additionally, because emotional exhaustion reduces employees' energy and relates to a perception of excessive organizational demands (Singh et al., 1994), emotional exhaustion negatively affects employees' advocacy of a company's image. More formally, $\mathrm{H}_{7}$ : Emotional exhaustion negatively affects favorable external representation of the workplace.

Organizational commitment reflects the strength of an employee's identification with and contributions to a particular organization (Mowday et al., 1979; Porter et al., 1974). Past research identifies organizational commitment as an antecedent of several employee behaviors that go beyond job requirements, such as organizational citizenship behaviors and pro-social behaviors (MacKenzie et al., 1998; Organ and Ryan, 1995; O’Reilly and Chatman, 1986). Although an employee's job specification does not directly prescribe these behaviors, employees perform them to benefit the organization as a whole (O'Reilly and Chatman, 1986). Bettencourt et al. (2005) suggest that employees' commitment to the organization also influences them to convey a positive image of the firm to outsiders (e.g., customers, competitors, suppliers). More formally, consider the following hypothesis. $\mathrm{H}_{8}$ : Organizational commitment positively affects favorable external representation of the workplace.

Together with organizational commitment, job satisfaction is a driver of pro-social employee behaviors, that is, employee behaviors and actions that a job description does not directly specify, but which the employee performs anyhow and which benefit the organization (Bettencourt et al., 2005; O’Reilly and Chatman, 1986). Job satisfaction positively relates to a set of organizational citizenship behaviors (Netmeyer, Boles, 
McKee, and McMurrian, 1997; Organ and Ryan, 1995) and extra-role behaviors

(MacKenzie et al., 1998). The norm of reciprocity offers the rationale for this

relationship: employees should not only help but also not hurt another individual who has

helped him or her (Gouldner, 1960). In particular, highly satisfied employees tend to carry out extra-role behaviors to show appreciation to the firm and to reciprocate their feeling of satisfaction (MacKenzie et al., 1998). More formally, $\mathrm{H}_{9}$ : Job satisfaction positively affects favorable external representation of the workplace.

\section{METHOD}

\subsection{Sample and Data Collection}

In line with recent research (cf. Harris and Ogbonna, 2010; Karatepe, Yavas, Babakus, and Avci, 2006), data have been collected from frontline restaurant/fast-food employees in the United Kingdom. Frontline service employees are the respondents in this study for two reasons. First, in many companies, due to their pivotal role in interacting with the customer, they comprise "the first and only representation of a service firm" to the outside world (Hartline et al., 2000: 35). Therefore, frontline service employees are in a unique position to convey their opinions of the company to outsiders. Second, frontline service employees are particularly vulnerable to emotional exhaustion since they have one-to-one interface with clients (cf. Singh et al., 1994). Additionally, the restaurant/fast-food setting was deemed appropriate for this study due to the close contact between customers and employees and the economic importance of this sector (Harris and Ezeh, 2008; Harris and Ogbonna, 2002). 
The author sent all 2,324 company's employees an envelope containing a cover letter describing the study and a questionnaire. To encourage honesty, the cover letter assured employees of confidentiality. As requested in the cover letter, restaurant/fast-food employees completed the questionnaire anonymously during working hours and returned the questionnaire in a sealed, stamped, pre-addressed envelope to the researcher. Of the 2,324 employees who were sent the survey questionnaire, 839 returned the questionnaire, resulting in a raw response rate of 36.1 percent. After removing 99 non-valid questionnaires, the final response rate is 31.8 percent. The usable response rate is similar to that of previous research involving FSEs (e.g., Schwepker and Hartline, 2005; Hartline et al., 2000).

Women comprise the majority of the respondents, 61.9 percent, and most respondents, 60.5 percent, work full-time. Approximately 10 percent of the respondents are younger than 18, 42.4 percent are between 18 and 24, and 15.7 percent are between 25 and 29 years old. The remaining respondents are above 30 years old. Concerning the level of education of the respondents, 17.7 percent have GCSEs, 25.8 percent have NVQ/GNVQs and 19.4 percent have A-levels. Seven percent have no qualification, 4.1 percent hold an Undergraduate degree and 2.1 percent have a Master's degree.

The frontline employee had been working on average 5 years and 3 months in this industry, 3 years and 5 months for this particular company, and 3 years and 4 months for the restaurant/fast-food outlet. On average, FSEs spend 76.3 percent of their time in contact with customers. 


\subsection{Assessment of non-response bias}

An extrapolation method, which assumes that late respondents are more similar to non-respondents, enables the estimation of non-response bias (Armstrong and Overton, 1977). Accordingly, this study defines early respondents as the first $75 \%$ to send the questionnaire back and late respondents as the remaining 25\% (Lages, Silva, and Styles, 2009) and compares early and late respondents with regard to all the items of interest, age, gender, industry tenure, company tenure and proportion of time in contact with the customers. Results of $t$-tests on independent samples show non-significant differences between early and late respondents for the majority of variables suggesting that nonresponse bias is not a significant issue in this study (Diamantopoulos and Winklhofer, 2001).

\subsection{Assessment of common method biases}

Common method variance can inflate or deflate relationships among constructs. Possible sources of common method bias include when data on different variables are collected at the same point in time, from the same respondent, and using the same medium (Podsakoff, MacKenzie, Lee, and Podsakoff, 2003). This study follows procedures that Podsakoff et al. (2003) suggest to control for common method biases. The author took precautions to 1) ensure the clarity, succinctness, and precision of questionnaire items, 2) ensure different scale formats and anchors ("strongly disagree" to "strongly agree" vs. "not at all characteristic of me" to "extremely characteristic of me") and values (1-5 vs. $1-7), 3)$ provide a low-bias data collection medium, that is, paperand-pencil questionnaires, rather than face-to-face interviews, 4) control for social desirability and obtain responses reflecting employees' true feelings by guaranteeing in 
writing respondents' anonymity, 5) encourage respondents to provide their honest

opinions by stating that the questionnaire had no right or wrong answers, and 6) counter the bias effect that implicit theories may have on respondents' answers by withholding information about the study's conceptual framework. These procedures help control for common method bias.

\subsection{Measures}

The survey includes measures of workgroup support, emotional exhaustion, organizational commitment, job satisfaction, and favorable external representation of the workplace. The author operationalized all constructs using sound measures drawn from the literature. To guarantee high-quality data, a balance between designing a brief survey instrument and using multi-item scales prompted the use of short versions of the scales when available (cf. Singh et al., 1994).

The workgroup support scale measures the degree to which FSEs socialize in a positive and supportive way with other employees (cf. Hartline et al., 2000). The study assesses workgroup support using an adaptation of Hartline et al.'s (2000) measure of workgroup socialization. This study measures emotional exhaustion, which reflects "feelings of being emotionally overextended and drained by one's contact with other people" (Leiter and Maslach, 1988: 297), using an adaptation of the Maslach Burnout Inventory (MBI) scale (Maslach and Jackson, 1981, 1986).

The study measures organizational commitment with Hartline et al.'s (2000) short version of the scale developed by Mowday et al. (1979), which assesses the degree to which employees feel affectively committed to the employing organization. Job satisfaction reflects an employee's psychological well-being on the job (Singh et al., 
1994). Judge and Colquitt's (2004) short version of the scale developed by Brayfield and Rothe (1951) measures job satisfaction. Favorable external representation of the workplace assesses the extent to which employees promote a positive image of the company to people outside the organization. This study uses Bettencourt and Brown's (2003) scale to measure external representation of the workplace.

The results reveal a high internal reliability for all scales (Cronbach, 1951). Cronbach's alphas for the workgroup support, emotional exhaustion, organizational commitment, job satisfaction, and favorable external representation measures are $.77, .87, .93, .87$, and .87 , respectively (see Table 1 ).

Table 1 here.

\section{RESULTS}

\subsection{Confirmatory factor analysis}

To assess the validity of the measures, the items were subjected to a confirmatory factor analysis using maximum likelihood estimation procedures in LISREL 8.72 (Jöreskog and Sörbom, 2001). Despite the significant chi-square $\left(\chi^{2}=263.96 ; \mathrm{df}=109\right.$; $\mathrm{p}=.00)$, the final measurement model fits the data well $(\mathrm{NFI}=.99, \mathrm{NNFI}=.99, \mathrm{CFI}$ $=.99, \mathrm{IFI}=.99$, and RMSEA $=.044)$.

All constructs reveal discriminant validity as shown in Table 1 . The average variance extracted for each construct is superior to the squared correlation coefficient 
between that construct and all other constructs (Fornell and Larcker, 1981). To assess convergent validity, this study examines the magnitude and the statistical significance $(t-$ values) of the factor loading estimates. All path coefficients are highly significant, and the average loading size is .81 (cf. Hair, Black, Anderson, Babin, and Tatham, 2006). In addition, each construct has an average variance extracted superior to .5 , suggesting adequate convergence (Fornell and Larcker, 1981). With regard to composite reliability $\rho$ - (Bagozzi, 1980), values of .70 or higher indicate good reliability (Hair et al., 2006). Composite reliability ranges from .78 for workgroup support to .93 for organizational commitment. Table 1 presents the measurement model results including standardized loadings, $t$-values, internal reliability, variance extracted, composite reliability, and model fit.

\subsection{Hypotheses testing}

\section{Direct effects}

The study employs a structural equation modeling approach to test the nine hypotheses using LISREL 8.72 (Jöreskog and Sörbom, 2001). Although the chi-square is significant $\left(\chi^{2}=274.59, \mathrm{df}=110, \mathrm{p}=.00\right)$, all the indices suggest a good fit of the final model to the data: NFI $=.99, \mathrm{NNFI}=.99, \mathrm{CFI}=.99, \mathrm{IFI}=.93$, and RMSEA $=.045$.

With regard to the impact of an appraisal process on emotional responses (cf. Bagozzi, 1992), the results confirm hypothesis 1. Workgroup support negatively influences emotional exhaustion $(-.46, \mathrm{p}<.01)$. Similarly, the findings corroborate hypotheses 2 and 3. Workgroup support positively influences both organizational commitment $(.20, \mathrm{p}<.01)$ and job satisfaction $(.56, \mathrm{p}<.01)$. 
Regarding the effects among the three emotional responses, emotional exhaustion negatively influences both organizational commitment $(-.10, \mathrm{p}<.05)$ and job satisfaction $(-.27, \mathrm{p}<.01)$, which supports hypotheses 4 and 5 . Additionally, job satisfaction has a positive effect on organizational commitment $(.61, \mathrm{p}<.01)$, which supports hypothesis 6 . Finally, with regard to the impact of emotional responses on behavior (cf. Bagozzi 1992), three factors drive favorable external representation: emotional exhaustion $(-.13, \mathrm{p}<.01)$, organizational commitment $(.59, \mathrm{p}<.01)$, and job satisfaction $(.20, \mathrm{p}<.01)$, which support hypotheses 7, 8, and 9 (see Figure 2, Table 2). Thus, the findings support the nine hypothesized direct relationships.

Figure 2 here.

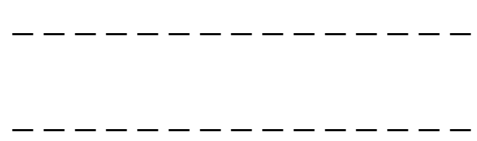

Table 2 here.

\section{Indirect and total effects}

A path model enables the estimation of the direct effects as well as the indirect and total effects among latent variables (Bollen, 1989). While the previous section discusses the direct effects, this section focuses on the indirect and total effects. Table 2 shows six statistically significant indirect effects. With regard to the indirect effects between the appraisal process and emotional responses (cf. Bagozzi, 1992), the indirect effect of workgroup support on job satisfaction $(.13, \mathrm{p}<.01)$ through emotional exhaustion is positive and statistically significant. Therefore, the indirect relationship 
strengthens the total effect $(.69, \mathrm{p}<.01)$. Similarly, the results indicate a positive and statistically significant indirect effect of workgroup support on organizational commitment $(.47, \mathrm{p}<.01)$ through job satisfaction and emotional exhaustion. Thus, the indirect relationship also strengthens the total effect $(.67, \mathrm{p}<.01)$.

When considering the effects among emotional responses, the negative indirect impact of emotional exhaustion on organizational commitment through job satisfaction $(-.17, \mathrm{p}<.01)$ strengthens the total negative effect $(-.26, \mathrm{p}<.01)$. Finally, with regard to the effects between emotional responses and behavior (cf. Bagozzi, 1992), the results indicate a negative and statistically significant indirect impact of emotional exhaustion on employees' favorable external representation of the workplace $(-.21, \mathrm{p}<.01)$ through organizational commitment and job satisfaction. Consequently, the total negative effect becomes stronger $(-.34, \mathrm{p}<.01)$. Additionally, the findings show a positive, significant indirect impact of job satisfaction on favorable external representation $(.36, \mathrm{p}<.01)$ through organizational commitment. Accordingly, the indirect relationship strengthens its total effect $(.56, \mathrm{p}<.01)$. Finally, the results show a highly significant indirect impact of workgroup support on favorable external workplace representation through all three emotional responses $(.59, \mathrm{p}<.01)$.

\section{Relative contribution}

By drawing on Bagozzi’s (1992) work, this study investigates the relative importance of key drivers of job satisfaction and organizational commitment (i.e., emotional responses), and favorable external representation of the workplace (i.e., coping response/behavior). When analyzing the key antecedents of job satisfaction, workgroup support, a highly neglected job satisfaction driver in the Marketing literature, is twice as 
influential $(.56, \mathrm{p}<.01)$ as reduced emotional exhaustion $(-.27, \mathrm{p}<.01)$ in explaining job satisfaction.

Regarding the key antecedents of organizational commitment, the results reveal that job satisfaction $(.61, \mathrm{p}<.01)$ is three times more influential than workgroup support $(.20, \mathrm{p}<.01)$ and six times more important than reduced emotional exhaustion $(-.10, \mathrm{p}$ $<.05)$ in accounting for organizational commitment. Finally, with regard to the relative importance of each of the key antecedents of employees' favorable external representation, the findings show that the impact of organizational commitment $(.59, \mathrm{p}$ $<.01)$ is four times greater than reduced emotional exhaustion $(-.13, \mathrm{p}<.01)$ and three times greater than job satisfaction $(.20, \mathrm{p}<.01)$ in explaining external representation of the workplace (see Table 2). The analysis of the relative contribution is important from a managerial perspective since this analysis provides guidelines regarding which factors contribute most for the outcome variable.

\section{DISCUSSION, LIMITATIONS AND CONCLUSIONS}

By drawing on Bagozzi's (1992) reformulation of attitude theory, and in particular the self-regulatory processes, this study investigates the relationships among workgroup support, emotional exhaustion, job satisfaction, organizational commitment, and favorable external representation. The findings reveal that the nine hypothesized direct effects and the six indirect effects and corresponding total effects are significant.

The study's contribution to the Marketing literature is, therefore, fourfold. First, anchored in Bagozzi's (1992) work, this research proposes a new conceptual framework, which incorporates workgroup support as an appraisal process; emotional exhaustion, 
organizational commitment, and job satisfaction as emotional responses; and favorable external representation of the workplace as a coping response/behavior. In particular, findings show the impact of workgroup support on external representation indirectly through its effects on three emotional responses of employees, that is, emotional exhaustion, organizational commitment and job satisfaction.

Second, this study contributes to the Marketing literature by theoretically proposing and empirically testing for the first time the relationship between workgroup support and three emotional responses, namely emotional exhaustion, organizational commitment and job satisfaction. In addition to studying these three new direct relationships, this paper investigates for the first time the indirect effects of emotional responses (i.e., job satisfaction and emotional exhaustion) in the relationship between workgroup support and organizational commitment, as well as the indirect effect of emotional exhaustion in the relationship between workgroup support and job satisfaction. The results reveal that the positive impact of workgroup support on organizational commitment is stronger when considering the indirect effects through enhanced job satisfaction and reduced emotional exhaustion. Additionally, findings also show that the positive effect of workgroup support on job satisfaction becomes stronger through reduced emotional exhaustion.

Third, with regard to the impact of emotional responses on external representation of the workplace, this study builds on previous literature (cf. Bettencourt and Brown, 2003; Bettencourt, Brown, and MacKenzie, 2005) by proposing a more comprehensive set of emotional responses. In particular, given that this body of literature ignores the role of emotional exhaustion in determining external representation of the workplace, this 
study fills a gap by including emotional exhaustion as an emotional response and investigating its impact on external representation. Results reveal that the negative impact of emotional exhaustion on favorable external representation becomes even stronger when considering the indirect effects of diminished commitment to the organization and reduced job satisfaction as a consequence of emotional exhaustion.

Fourth, and in contrast to most empirical studies in the Marketing field, this research investigates the relative importance of key antecedents of external representation of the workplace. Findings reveal that in addition to the indirect effect of workgroup support, three emotional responses play a major role in promoting favorable external representation: (1) reduced emotional exhaustion, (2) job satisfaction, and (3) organizational commitment (in increasing order of importance).

While these results significantly advance the understanding of external representation of the workplace, an important Marketing area, this study's limitations and suggestions for further research in the context of these limitations are discussed. First, the data collection took place at one specific point in time using one type of respondent (i.e., frontline service employees). To reduce possible common-method bias, this study employed a number of procedures as Podsakoff et al. (2003) suggest. Nonetheless, future studies could employ a longitudinal research design or use respondents who hold different positions (e.g., non-frontline workers such as back-office employees) within a firm and across firms. Selecting frontline service employees remains appropriate, though, given their particular vulnerability to emotional exhaustion (cf. Singh et al., 1994) and their key role in directly interacting with customers (Hartline et al., 2000), which gives them a privileged position to reflect the company's image to outsiders. 
Second, a single organization provides the context for this research, which may limit the generalization of the results. Nevertheless, using a single-company research design can control for contextual effects, such as corporate culture and service delivery types (Piercy, Cravens, Lane, and Vorhies, 2006), which is a significant advantage.

Finally, this study focuses on a single industry (i.e., restaurants and fast-food).

Further research in other service industries (e.g., airlines, banking, hotel services) would enhance the generalization of the results. Despite these limitations, this study's findings deepen and illuminate the research on favorable external representation. In particular, this study uncovers a noteworthy finding: the significant indirect relationship between workgroup support and employees' favorable external representation of the workplace through all three emotional responses studied (i.e., emotional exhaustion, organizational commitment, and job satisfaction), which suggests a mediating role of emotional responses. Analysis of the specific key antecedents of job satisfaction also uncovers an interesting finding: that workgroup support, a driver overlooked in the Marketing literature, is more important than reduced emotional exhaustion in explaining job satisfaction. Indeed, results reveal that the positive effect of workgroup support on job satisfaction becomes stronger through reduced emotional exhaustion. Together these results highlight the key pivotal role of workgroup support. Accordingly, management needs to continually promote team members' support by developing and implementing specific activities and practices, and develop corporate values that encourage workgroup support in order to enhance job satisfaction and organizational commitment, and reduce emotional exhaustion. This approach would ultimately lead to enhanced external representation of the workplace. 
When identifying the key antecedents of organizational commitment, the findings reveal that job satisfaction is the most important driver, followed by workgroup support and, finally, reduced emotional exhaustion. This result suggests that to increase the likelihood that potential employees will feel satisfied with their jobs; managers should clearly convey the organization's vision and goals, as well as its expectations regarding employee performance, during the hiring process.

Finally, with regard to the key antecedents of favorable external representation, the results show that organizational commitment is more important than job satisfaction and reduced emotional exhaustion in explaining favorable external representation. This finding highlights the importance of employees' organizational commitment. A close alignment of values and beliefs between the potential employee and the company could prove to be a major step toward developing organizational commitment. Thus, recruitment and selection committees should clearly explain to future employees the company's values and workplace environment (cf. Netemeyer, Boles, McKee, and McMurrian, 1997). In addition, while interviewing candidates, managers should carefully assess the extent to which potential employees' values, goals and beliefs align with those of the organization (Wiener, 1982) rather than expecting employees to adjust to those of the organization after being recruited.

In summary, the literature (e.g., Bettencourt and Brown, 2003; Bettencourt et al., 2005) and business practice (e.g., Fortune's “100 Best Companies to Work For”) emphasize the importance of companies developing and implementing strategies that enhance employees' favorable verbal expressions about the workplace to outsiders. From a theoretical perspective, results demonstrate that Bagozzi’s (1992) self-regulatory 
processes do indeed constitute a solid theoretical framework for understanding the impact of workgroup support on external representation behavior, mediated by emotional responses. From a business practice viewpoint, this study shows managers the relevance of self-regulatory processes in developing a favorable external representation. Managers should create a workplace environment in which workgroup support takes place on a continuous basis. Moreover, managers should place greater relative emphasis on promoting and developing employees' organizational commitment given its high impact on favorable external representation behavior. These actions will, ultimately, improve the company’s performance. 


\section{REFERENCES}

Alexandrov A, Babakus E, Yavas U. The effects of perceived management concern for frontline employees and customers on turnover intentions: moderating role of employment status. Journal of Service Research 2007; 9: 356-371.

Allen NJ, Meyer JP. Organizational socialization tactics: a longitudinal analysis of links to newcomers' commitment and role orientation. Academy of Management Journal 1990; 33: 847-58.

Allen NJ, Meyer JP. Organizational commitment: Evidence of career-stage effects? Journal of Business Research 1993; 26: 49-61.

Armeli S, Eisenberger R, Fasolo P, Lynch PD. Perceived organizational support and police performance: the moderating influence of socioemotional needs. Journal of Applied Psychology 1998; 83: 288-297.

Armstrong JS, Overton TS. Estimating nonresponse bias in mail surveys. Journal of Marketing Research 1977; 14: 396-402.

Aryee S, Chayt YW. An examination of the impact of career-oriented mentoring on work commitment attitudes and career satisfaction among professional and managerial employees. British Journal of Management 1994; 5: 241-249. 
Babakus E, Cravens DW, Johnston M, Moncrief WC. The role of emotional exhaustion in sales force attitude and behavior relationships. Journal of the Academy of Marketing Science 1999; 27: 58-70.

Babakus E, Yavas U, Karatepe OM, Avci T. The effect of management commitment to service quality on employees' affective and performance outcomes. Journal of the Academy of Marketing Science 2003; 31: 272-286.

Bagozzi RP. Causal models in marketing. New York: John Wiley, 1980.

Bagozzi RP. The self-regulation of attitudes, intentions, and behavior. Social Psychology Quarterly 1992; 55: 178-204.

Bettencourt LA, Brown SW. Role stressors and customer-oriented boundary-spanning behaviors in service organizations. Journal of the Academy of Marketing Science 2003; 31: 394-408.

Bettencourt LA., Brown SW, MacKenzie SB. Customer-oriented boundary-spanning behaviors: test of a social exchange model of antecedents. Journal of Retailing 2005; 81: 141-157.

Bollen, KA. Structural Equations with Latent Variables. New York: John Wiley, 1989. 
Boshoff C, Mels G. The impact of multiple commitments on intentions to resign: an empirical assessment. British Journal of Management 2000; 11: 255-272.

Brashear TG, Boles JS, Bellenger DN, Brooks CM. An empirical test of trust-building processes and outcomes in sales manager-salesperson relationships. Journal of the Academy of Marketing Science 2003; 31: 189-199.

Brayfield AH, Rothe HF. An index of job satisfaction, Journal of Applied Psychology $1951 ; 35: 307-311$.

Brown SP, Peterson RA. Antecedents and consequences of salesperson job satisfaction: meta-analysis and assessment of causal effects. Journal of Marketing Research 1993; 30: 63-77.

Cronbach LJ. Coefficient alpha and the internal structure of tests. Psychometrika 1951; 16: $297-334$.

Cropanzano R, Howes JC, Grandey AA, Toth P. The relationship of organizational politics and support to work behaviors, attitudes, and stress. Journal of Organizational Behavior 1997; 18: 159-180. 
Cropanzano R, Rupp DE, Byrne ZS. The relationship of emotional exhaustion to work attitudes, job performance, and organizational citizenship behaviors. Journal of Applied Psychology 2003; 88: 160-169.

Cropanzano R, Rupp DE, Mohler CJ, Schminke M. Three roads to organizational justice. In: Ferris, J, editor. Research in Personnel and Human Resources Management, vol. 20. Greenwich, CT: JAI Press, 2001. pp. 1-113.

Diamantopoulos A, Winklhofer HM. Index construction with formative indicators: An alternative to scale development. Journal of Marketing Research 2001; May: 269-277.

Eisenberger R, Fasolo P, Davis-LaMastro V. Perceived organizational support and employee diligence, commitment, and innovation. Journal of Applied Psychology 1990; 75 (1): 51-59.

Eisenberger R, Huntington R, Hutchison S, Sowa D. Perceived organizational support. Journal of Applied Psychology 1986; 71: 500-507.

Fornell C, Larcker DF. Evaluating structural equation models with unobservable variables and measurement error. Journal of Marketing Research 1981; 18: 39-50. 
George JR, Bettenhausen K. Understanding prosocial behavior, sales performance and turnover: a group-level analysis in a service context. Journal of Applied Psychology 1990; 75: 698-709.

Gouldner AW. The norm of reciprocity: a preliminary statement. American Sociological Review 1960; 25: 161-178.

Hair JF, Black WC, Anderson RE, Babin BJ., Tatham RL. Multivariate Data Analysis. Upper Saddle River, NJ: Pearson Education, 2006.

Harris LC, Ezeh C. Servicescape and loyalty intentions: an empirical investigation. European Journal of Marketing 2008; 42: 390-422.

Harris LC, Ogbonna E. Exploring service sabotage: the antecedents, types and consequences of frontline, deviant, antiservice behaviors. Journal of Service Research 2002; 4: 163-183.

Harris LC, Ogbonna E. Hiding customer complaints: studying the motivations and forms of service employees complaint concealment behaviors. British Journal of Management 2010; 21: 262-279. 
Hartline MD, Maxham III JG, McKee DO. Corridors of influence in the dissemination of customer-orientated strategy to customer contact service employees. Journal of Marketing 2000; 64: 35-50.

Hewlin PF. Wearing the cloak: antecedents and consequences of creating facades of conformity. Journal of Applied Psychology 2009; 94: 727-741.

Jackson SE, Turner JA, Brief AP. Correlates of burnout among public service lawyers. Journal of Occupational Behavior 1987; 8: 339-349.

Janssen O, Van Yperen NW. Employees' goal orientations, the quality of leader-member exchange, and the outcomes of job performance and job satisfaction. Academy of Management Journal. 2004; 47: 368-384.

Jaramillo F, Mulki JP, Marshall GW. A meta-analysis of the relationship between organizational commitment and salesperson job performance: 25 years of research. Journal of Business Research 2005; 58: 705-714.

Johnson RE, Groff KW, Taing MU. Nature of the interactions among organizational commitments: complementary, competitive or synergistic? British Journal of Management 2009; 20: 431-447. 
Johnston MW, Parasuraman A, Futrell CM and Black WC. A longitudinal assessment of the impact of selected organizational influences on salespeople's organizational commitment during early employment. Journal of Marketing Research 1990; 27: 333344.

Judge TA, Colquitt JA. Organizational justice and stress: the mediating role of workfamily conflict. Journal of Applied Psychology 2004; 89: 395-404.

Jöreskog KG, Sörbom D. LISREL 8: User's Reference Guide. Lincolnwood, IL: Scientific Software International, 2001.

Karatepe OM. The effects of selected antecedents on the service recovery performance of frontline employees. The Service Industries Journal 2006; 26 (1): 39-57.

Karatepe OM, Yavas U, Babakus E, Avci T. Does gender moderate the effects of role stress in frontline service jobs? Journal of Business Research 2006; 59: 1087-1093.

Kim HJ, Knight DK, Crutsinger C. Generation Y employees' retail work experience: The mediating effect of job characteristics. Journal of Business Research 2009; 62: 548-556.

Kram KE. Mentoring at Work: Developmental Relationships in Organizational Life.

Glenview, IL: Scott, Foresman, 1985. 
Lages LF, Silva G, Styles C. Relationship capabilities, quality, and innovation as determinants of export performance. Journal of International Marketing, Special Issue on The Performance Implications of International Marketing Strategy 2009; 17: 47-70.

Lazarus RS. Emotion and Adaptation. New York: Oxford University Press, 1991.

Lankau MJ, Scandura TA. An investigation of personal learning in mentoring relationships: content, antecedents, and consequences. Academy of Management Journal 2002; 45: 779-790.

Lee RT, Ashforth BE. A meta-analytic examination of the correlates of the three dimensions of job burnout. Journal of Applied Psychology 1996; 81: 123-133.

Leiter MP, Maslach C. The impact of interpersonal environment on burnout and organization commitment. Journal of Organizational Behavior 1988; 9: 297-308.

MacKenzie SB, Podsakoff PM, Ahearne M. Some possible antecedents and consequences of in-role and extra-role salesperson performance. Journal of Marketing 1998; 62: 87-98.

Maslach C, Jackson SE. The measurement of experienced burnout. Journal of Occupational Behavior 1981; 2: 99-113. 
Maslach C, Jackson SE. Maslach Burnout Inventory Manual. Palo Alto, CA: Consulting Psychologists Press, 1986.

Mathieu JE, Zajac DM. A review and meta-analysis of the antecedents, correlates, and consequences of organizational commitment. Psychological Bulletin 1990; 108: 171-194.

Mowday RT, Porter LW, Steers RM. Employee-Organization Linkages: The Psychology of Commitment, Absenteeism, and Turnover. New York: Academic Press, 1982.

Mowday RT, Steers RM, Porter LW. The measurement of organizational commitment. Journal of Vocational Behavior 1979; 14: 224-247.

Mulki JP, Jaramillo F, Locander WB. Emotional exhaustion and organizational deviance: Can the right job and a leader's style make a difference? Journal of Business Research 2006; 59: 1222-1230.

Netemeyer RG, Boles JS, McKee DO, McMurrian R. An investigation into the antecedents of organizational citizenship behaviors in a personal selling context. Journal of Marketing 1997; 61: 85-98.

O'Reilly C III, Chatman J. Organizational commitment and psychological attachment: the effects of compliance, identification, and internalization on prosocial behavior. Journal of Applied Psychology 1986; 71: 492-499. 
Organ DW, Ryan K. A meta-analytic review of attitudinal and dispositional predictors of organizational citizenship behavior. Personnel Psychology 1995; 48: 775-802.

Piercy NF, Cravens DW, Lane N, Vorhies DW. Driving organizational citizenship behaviors and salesperson in-role behavior performance: the role of management control and perceived organizational support. Journal of the Academy of Marking Science 2006; 34: 244-262.

Podsakoff PM, Ahearne M, MacKenzie SB. Organizational citizenship behavior and the quantity and quality of work group performance. Journal of Applied Psychology 1997; 82: $262-270$.

Podsakoff PM, MacKenzie SB, Lee JY, Podsakoff NP. Common method biases in behavioral research: a critical review of the literature and recommended remedies. Journal of Applied Psychology 2003; 88: 879-903.

Porter LW, Steers RM, Mowday RT, Boulian, PV. Organizational commitment, job satisfaction, and turnover among psychiatric technicians. Journal of Applied Psychology 1974; 59: 603-609.

Rhoades L, Eisenberger R. Perceived organizational support: a review of the literature. Journal of Applied Psychology 2002; 87: 698-714. 
Riggle RJ, Edmondson DR, Hansen JD. A meta-analysis of the relationship between perceived organizational support and job outcomes: 20 years of research. Journal of Business Research 2009; 62: 1027-1030.

Schwepker CH, Hartline MD. Managing the ethical climate of customer-contact service employees. Journal of Service Research 2005; 7: 377-397.

Self DR, Holt DT, Schaninger WS Jr. Work-group and organizational support: a test of distinct dimensions. Journal of Occupational and Organizational Psychology 2005; 78: 133-140.

Settoon RP, Bennett N, Liden RC. Social exchange in organizations: perceived organizational support, leader-member exchange, and employee reciprocity. Journal of Applied Psychology 1996; 81 (3): 219-27.

Singh J, Goolsby JR, Rhoads GK. Behavioral and psychological consequences of boundary-spanning burnout for customer service representatives. Journal of Marketing Research 1994; 31: 558-569.

Singh J, Verbeke W, Rhoads GK. Do organizational practices matter in role stress processes? A study of direct and moderating effects for marketing-oriented boundary spanners. Journal of Marketing 1996; 60: 69-86. 
Snipes RL, Oswald SL, LaTour M, Armenakis AA. The effects of specific job satisfaction facets on customer perceptions of service quality: an employee-level analysis. Journal of Business Research 2005; 58: 1330-1339.

Strauss K, Griffin MA, Rafferty AE. Proactivity directed toward the team and organization: the role of leadership, commitment and role-breadth self-efficacy. British Journal of Management 2009; 20: 279-291.

Van Maanen J, Schein EH. Toward a theory of organizational socialization. In: BM. Staw, editor. Research in Organizational Behavior. Greenwich, CT: JAI Press, 1979, 209-264.

Wiener Y. Commitment in organizations: a normative view. Academy of Management Review 1982; 7: 418-428. 
Table 1: Measurement Model

Factors

Standardized

Loadings $^{a}$

Work Group Support $\left(\alpha=.77 / \rho_{\mathrm{vc}(\mathrm{n})=.} .54 / \rho=.78\right)$

I am gaining a clear understanding of my role in this unit by observing my senior colleagues. ${ }^{b}$

.68

Almost all of my colleagues have been supportive of me personally.

My colleagues have gone out of their way to help me to adjust to this unit.

$.78(14.54)$

Emotional Exhaustion $\left(\alpha=.87 / \rho_{\mathrm{vc}(\mathrm{n})=.} .61 / \rho=.86\right)$

I feel emotionally drained by my work. ${ }^{b}$

I feel burned out from my job.

$.71(18.39)$

I worry that this job is hardening me emotionally.

$.78(24.46)$

Organizational Commitment $\left(\alpha=.93 / \rho_{\mathrm{vc}(\mathrm{n})=.} .78 / \rho=.93\right)$

I find that my values and [company name]'s values are very similar. ${ }^{\mathrm{b}}$

I am proud to tell others that I am a part of [company name].

[Company name] inspires the very best in me in the way of job performance.

For me, [company name] is the best of all possible organizations to work for.

Job Satisfaction $\left(\alpha=.87 / \rho_{\mathrm{vc}(\mathrm{n})=} .68 / \rho=.87\right)$

Most days I am enthusiastic about my work. ${ }^{\text {b }} \quad .83$

I feel fairly satisfied with my present job.

I find real enjoyment in my work.

\section{Favorable External Representation of the Workplace}

$\left(\alpha=.87 / \rho_{\mathrm{vc}(\mathrm{n})=.70 / \rho=.87)}\right.$

I tell outsiders this is a great place to work. ${ }^{b}$

I generate favorable goodwill for this unit.

I say good things about this unit to others.

Goodness-of-Fit Statistics

$\chi_{(109)}^{2}=263.96, \mathrm{p}=.00$

$\mathrm{NFI}=.99 ; \mathrm{NNFI}=.99 ; \mathrm{CFI}=.99 ; \mathrm{IFI}=.99$

$\mathrm{RMSEA}=.044$

\footnotetext{
"t-values are in parenthese

${ }^{\mathrm{b}}$ Item fixed to set the scale

$\alpha=$ Internal reliability (Cronbach, 1951)

$\rho_{\mathrm{vc}(\mathrm{n})}=$ Average variance extracted (Fornell and Larcker, 1981)

$\rho_{=}$Composite reliability (Bagozzi, 1980)
} 
Table 2: Effects of exogenous and prior endogenous constructs

(Maximum likelihood estimation, $\mathrm{n}=740$ )

\begin{tabular}{|c|c|c|c|c|c|c|c|c|c|c|c|c|}
\hline \multirow[t]{2}{*}{$\begin{array}{l}\text { EFFECT } \\
\text { OF /ON }\end{array}$} & \multicolumn{3}{|c|}{$\begin{array}{l}\text { Y1 } \\
\text { Emotional } \\
\text { exhaustion }\end{array}$} & \multicolumn{3}{|c|}{$\begin{array}{c}\text { Y2 } \\
\text { Job } \\
\text { satisfaction }\end{array}$} & \multicolumn{3}{|c|}{$\begin{array}{c}\mathrm{Y} 3 \\
\text { Organizational } \\
\text { commitment }\end{array}$} & \multicolumn{3}{|c|}{$\begin{array}{c}\text { Y4 } \\
\begin{array}{c}\text { Favorable external representation } \\
\text { of the workplace }\end{array}\end{array}$} \\
\hline & Direct & Indirect & Total & Direct & Indirect & Total & Direct & Indirect & Total & Direct & Indirect & Total \\
\hline $\begin{array}{l}\text { X1 } \\
\text { Workgroup } \\
\text { support }\end{array}$ & $\begin{array}{c}. .46 \\
(-8.70) \\
H 1\end{array}$ & & $\begin{array}{l}.46^{* *} \\
(-8.70)\end{array}$ & $\begin{array}{c}\mathbf{. 5 6}^{* *} \\
\mathbf{( 1 0 . 1 7 )} \\
\text { H3 }\end{array}$ & $\begin{array}{l}.13^{* * *} \\
(5.19)\end{array}$ & $\begin{array}{c}.69^{* * *} \\
(13.00)\end{array}$ & $\begin{array}{c}.20 \\
\mathbf{( 3 . 9 0 )}^{* *} \\
\mathrm{H} 2\end{array}$ & $\begin{array}{l}.47^{* * *} \\
(9.98)\end{array}$ & $\begin{array}{c}.67^{* *} \\
(\mathbf{1 3 . 4 9})\end{array}$ & & $\begin{array}{l}.59^{* * *} \\
(13.51)\end{array}$ & $\begin{array}{l}.59^{* * *} \\
(13.51)\end{array}$ \\
\hline $\begin{array}{l}\text { Y1 } \\
\text { Emotional } \\
\text { exhaustion }\end{array}$ & & & & $\begin{array}{c}.27^{* * *} \\
(-5.71) \\
\text { H5 }\end{array}$ & & $\begin{array}{l}-.27^{* * 4} \\
(-5.71)\end{array}$ & $\begin{array}{c}-.10^{*} \\
(-2.54) \\
H 4\end{array}$ & $\begin{array}{l}-.17^{* * *} \\
(-5.01)\end{array}$ & $\begin{array}{l}-.266^{* *} \\
(-5.51)\end{array}$ & $\begin{array}{c}. .13^{* *} \\
(\mathbf{- 3 . 4 3}) \\
\text { H7 }\end{array}$ & $\begin{array}{l}.211^{* *} \\
(-5.85)\end{array}$ & $\begin{array}{l}-.34^{* *} \\
(-7.21)\end{array}$ \\
\hline $\begin{array}{c}\text { Y2 } \\
\text { Job } \\
\text { satisfaction }\end{array}$ & & & & & & & $\begin{array}{c}\mathbf{. 6 1}^{* *} \\
\mathbf{( 1 0 . 9 5 )} \\
\text { H6 }\end{array}$ & & $\begin{array}{c}.61{ }^{* * *} \\
(10.95)\end{array}$ & $\begin{array}{c}.20 \\
\mathbf{( 3 . 1 4}^{* *} \\
\text { H9 }\end{array}$ & $\begin{array}{l}.36^{* *} \\
(7.92)\end{array}$ & $\begin{array}{l}.56^{* * *} \\
(10.09)\end{array}$ \\
\hline $\begin{array}{c}\mathrm{Y} 3 \\
\text { Organizational } \\
\text { commitment }\end{array}$ & & & & & & & & & & $\begin{array}{c}\mathbf{5 9}^{* * *} \\
\mathbf{( 9 . 5 0 )} \\
\mathrm{H} 8\end{array}$ & & $\begin{array}{l}.59^{* * *} \\
(9.50)\end{array}$ \\
\hline
\end{tabular}

Notes: Values in upper rows are completely standardized estimates. Values in lower rows are $t$-values. $* \mathrm{p}<.05$ and $* * \mathrm{p}<.01$ (two-tailed test). Because of rounding, in one case the total effect is not the same as the direct effect plus the indirect effect.

Goodness-of-Fit Statistics: $\chi^{2}=274.59, \mathrm{df}=110, \mathrm{p}$-value $=.00 ; \mathrm{NFI}=.99, \mathrm{NNFI}=.99, \mathrm{CFI}=.99, \mathrm{IFI}=.93$ and RMSEA $=.045$. 
Figure 1

Conceptual Framework

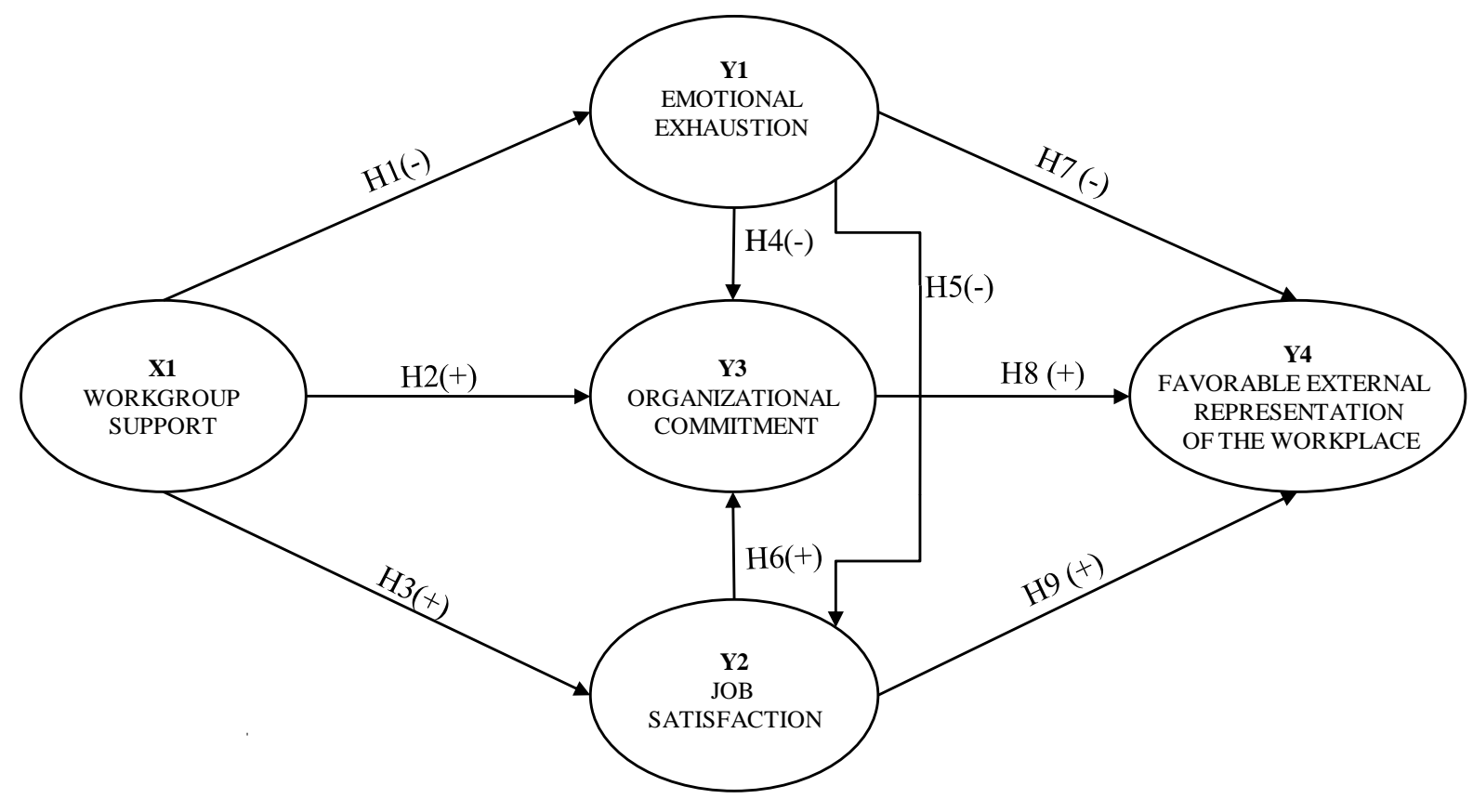

Appraisal $\longrightarrow$ Emotional Responses 
Figure 2

Results

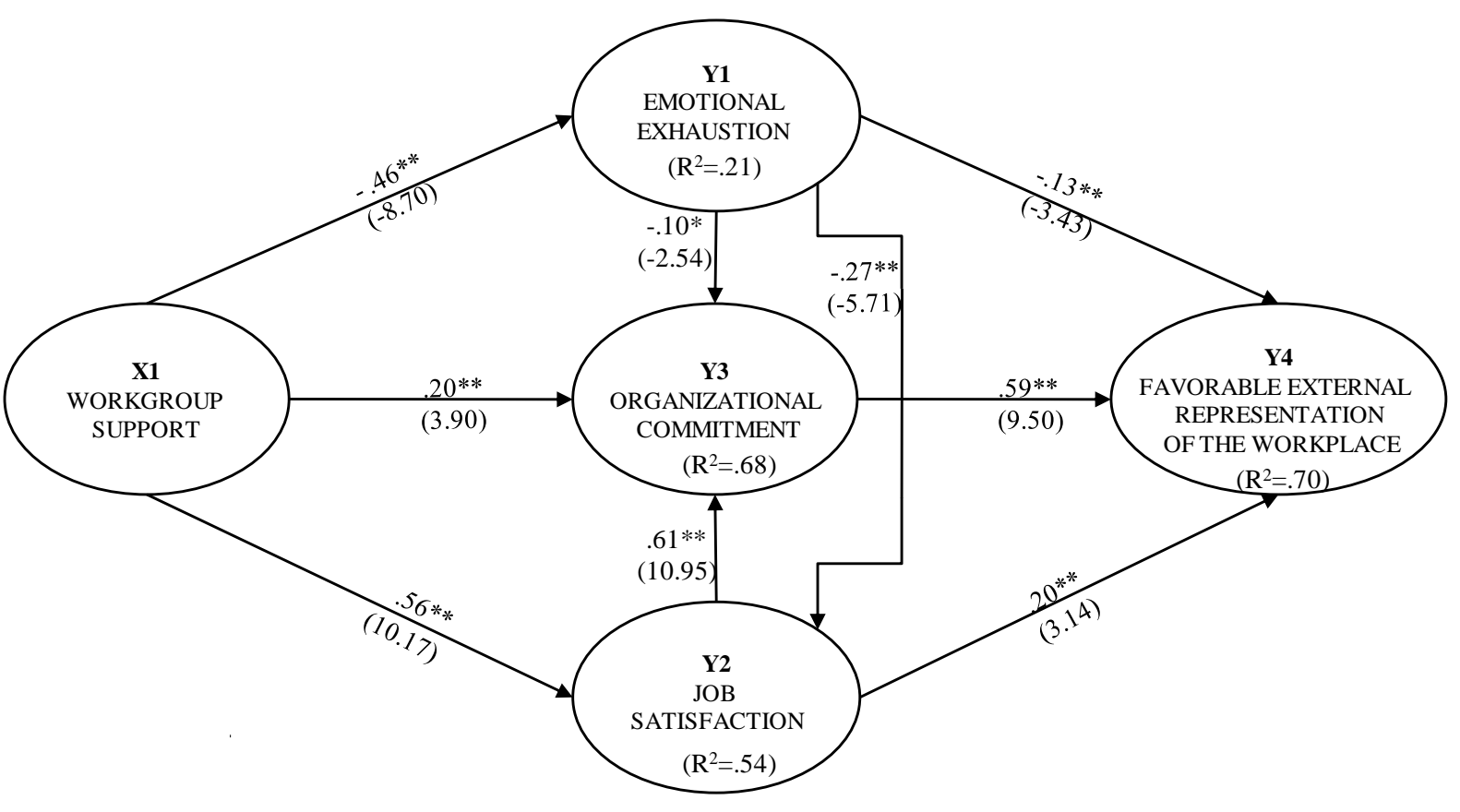

